\title{
CLIMATE CHANGE INDUCED MAJOR LIVELIHOOD CHANGES ON CHAR DWELLERS IN NORTHERN REGIONS OF BANGLADESH
}

\author{
M.A. Khatun*, M.A. Baten and M.A. Farukh \\ Department of Environmental Science \\ Bangladesh Agricultural University, Mymensingh, Bangladesh
}

\begin{abstract}
Bangladesh is one of the most vulnerable to climate change due to its geographic position and socio-economic context. The newly emerged land in the river channel is called char. The northern region especially Lalmonirhat, Kurigram, Gaibandha is most vulnerable. The study was carried out based on a questionnaire interview, focus group discussion, and secondary data sources from Bangladesh Meteorological Department (BMD). Climatic factors such as temperature (seasonal $\mathrm{T}_{\max }$ and $T_{\operatorname{mini}}$, daily average $T_{\max }$ and $T_{\operatorname{mini}}$ ), rainfall, sunshine, relative humidity, solar radiation intensity, sea level pressure and wind speed, etc. were detailed (how much change between before 2000s'and after the 2000s') studied in these areas. These are the main drivers that influence the vulnerability dimensions resulting in livelihood strategies and access to food, water, agricultural practices, income and overall livelihood, and leads to a vicious cycle of poverty. The study helps to understand the impacts of climate change, and natural disaster-related threats in the northern char area. Also suggested that if providing necessary institutional and organizational supports for strengthening the livelihood capitals, assets, and strategy to combat or mitigate impacts of climate change aspects in Bangladesh.
\end{abstract}

Keywords: Char land, Climate change, Livelihoods, Natural disasters

\section{INTRODUCTION}

Bangladesh is one of the most vulnerable to climate change. Due to geographic location especially in the monsoon climate, the country is highly vulnerable to natural disasters. It is the world's biggest delta, formed by the rivers Ganga, Brahmaputra and Meghna. About $63 \%$ of its population is employed in the sectors of agriculture, forests, and fisheries. Bangladesh and its population are thus, extremely vulnerable to the adverse effects of climate change. The scale and frequency of extreme climate

\footnotetext{
* Corresponding Author: amena.khatun592@gmail.com
} 
events have been steadily increasing, making survival difficult and expensive (Government of Bangladesh, Ministry of Environment and Forest, 2005). In general, char-lands are islands that adjoin rivers, but which are unshielded from the mainlands. Several sources (Mondal et al., 2015; Paul and Islam, 2015; Islam and Hossain, 2014; Kelly and Chowdhury, 2002) mentioned that 4-5\% of Bangladesh's total population of 160 million live in the chars, which cover approximately 7200 $\mathrm{km}^{2}$.

The char lands in Bangladesh are often perceived as a zone of multiple vulnerabilities (Paul and Islam, 2015). Among the different agro-ecological zones and hydrological regions of the country, the chars are particularly vulnerable to natural hazards, such as floods, erosion and drought, low and unstable land, remoteness from the mainland areas, and absence of extension and support services (Mondal et al., 2015). It is also evident that scarce rainfalls, excessive rainfalls, high temperatures, and delayed rains have a significant contribution to the crop-related changes in Bangladesh such as planting a higher-yielding, short duration, and drought-tolerant variety (Wood et al., 2014). The human distress, however, resulting from reduced crops and livestock production is widespread in low-lying regions. A large number of populations remain food insecure, social, immoral, and political instability, and insecurity pushed them to a vicious cycle of poverty. This is primarily the outcome of poor food access resulting from unequal land distribution, low agricultural wages, and the impact of natural disasters. The Government of Bangladesh (2011) has also acknowledged an information gap regarding the likely impacts of climate change and has highlighted the need to identify the most vulnerable sectors and geographical areas. The char people claimed that low access to food, water, and health amenities and fragile social network are the core drivers of livelihood venerability in the char land, as well as inadequate access to agriculture and nonagricultural property, and money (Hossain et al., 2020).

This current research has made an endeavor to assess the evolving risk to char livelihoods resulted from rapid climate variability. Hence, improved technology and infrastructures, strengthening social supports, and diversification of people's activities and assets can uplift livelihood opportunities (Ellis et al., 2000; Reed et al., 2013).

\section{MATERIALS AND METHODS}

\section{Study area}

A total of $23.27 \%$ area covering the northern regions of Bangladesh is situated in the Tista and Jamuna basin and contains many tributaries of these, especially Lalmonirhat, Kurigram, Gaibandha, and other districts. According to the Department of Agriculture Extension (DAE), there are $(127+300+91)=$ total 518 char's in these districts. 


\section{Data collection}

Primary data were collected from 400 Participants among three districts char. Various Govt. and non-Govt departments/stakeholders/service providers, staff, beneficiaries, and other relevant stakeholders were directly and indirectly associated with livelihood and climate-related issues from August 2019 to March 2020. Secondary data were collected from different journals, reports, research papers, websites, government, and non-government organizations. Various problems caused by climate change were measured by A. Income: a. Agricultural sources, b. Nonagricultural sources; B. Food security (availability of nutritious food every month of the year); C. Welfare (Table 1). In each condition 1 to 5 scale used both currently and 15 years ago.

Table 1. Changes in livelihood status among the various problems caused by climate change were measured by

\begin{tabular}{|c|c|c|c|c|c|c|c|c|c|c|}
\hline \multirow{3}{*}{ A. Income } & \multicolumn{10}{|c|}{ Different time conditions } \\
\hline & \multicolumn{5}{|c|}{ Currently } & \multicolumn{5}{|c|}{15 years ago } \\
\hline & $\vec{Z}_{0}^{2} \frac{11}{8}-$ & 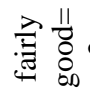 & $\begin{array}{ll}\overrightarrow{8} & \pi \\
0 & \pi\end{array}$ & $\begin{array}{l}\text { II } \\
\prod_{\mathscr{I}} \\
\text { ص }\end{array}$ & $\vec{D}$ & $\begin{array}{ll}\overrightarrow{7} & 11 \\
3 & 0 \\
> & 8 \\
\end{array}$ & 坣 $\frac{11}{8} \mathrm{O}$ & تृ & ت & 离告 \\
\hline \multicolumn{11}{|c|}{ a. Agricultural sources, b. Non-agricultural sources } \\
\hline \multirow{3}{*}{$\begin{array}{l}\text { B. Food } \\
\text { security } \\
\text { (availability of } \\
\text { nutritious food } \\
\text { every month of } \\
\text { the year) }\end{array}$} & \multicolumn{10}{|c|}{ The amount of food at different times } \\
\hline & \multicolumn{5}{|c|}{ Currently } & \multicolumn{5}{|c|}{15 years ago } \\
\hline & 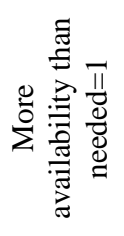 & 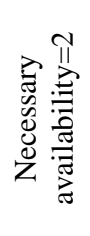 & 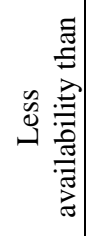 & 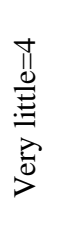 & 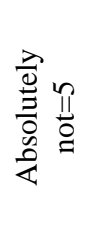 & 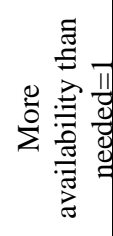 & 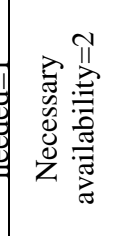 & 言 & 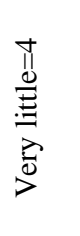 & 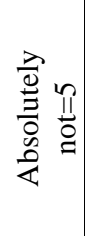 \\
\hline \multirow[b]{3}{*}{ C. Welfare } & \multicolumn{10}{|c|}{ Satisfaction levels at different times } \\
\hline & \multicolumn{5}{|c|}{ Currently } & \multicolumn{5}{|c|}{15 years ago } \\
\hline & 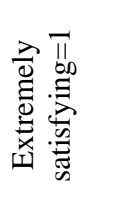 & 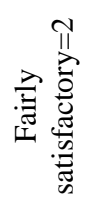 & 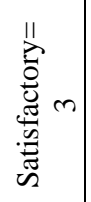 & 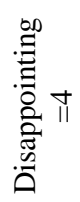 & 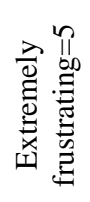 & 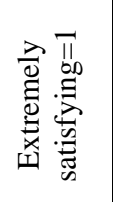 & 尝 & 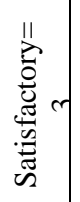 & 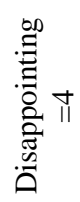 & 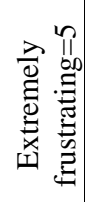 \\
\hline
\end{tabular}

\section{Data analysis}

The data obtained from the questionnaire method is processed with the use of simple mathematical tools as well as statistical Package for the Social Sciences (SPSS, version 25) for graphs and charts and MS Excel (2019). 3D Paint and Adobe Illustrator were used to process data into necessary information. 


\section{RESULTS AND DISCUSSION}

\section{Types of climate change and natural disaster-related threats}

In the study area, to know the types of climate change and natural disasters related threats, the current research investigated the major climatic factors such as temperature (seasonal $\mathrm{T}_{\max }$ and $\mathrm{T}_{\text {mini., }}$, daily average $\mathrm{T}_{\max }$ and $\mathrm{T}_{\operatorname{mini}}$ ), rainfall, sunshine, solar radiation intensity, sea level pressure and wind speed, etc (how much change between before 2000s' and after the 2000s').

\section{Changes in temperature}

Temperature data from the Bangladesh Meteorological Department (BMD) over the period 1970-2019 shows that the increasing trend of seasonal maximum temperatures is mainly due to increasing autumn and winter maximum temperatures of about an average difference of $7^{\circ} \mathrm{C}$. Spring and summer average maximum temperatures increased as well, but only by about $2-3^{\circ} \mathrm{C}$ (Figure.4a). Whereas seasonal minimum temperatures trend in winter has increased by $\approx 2^{\circ} \mathrm{C}$ and differences between seasonal autumn and winter minimum temperatures of about $13^{\circ} \mathrm{C}$ (Fig.1).

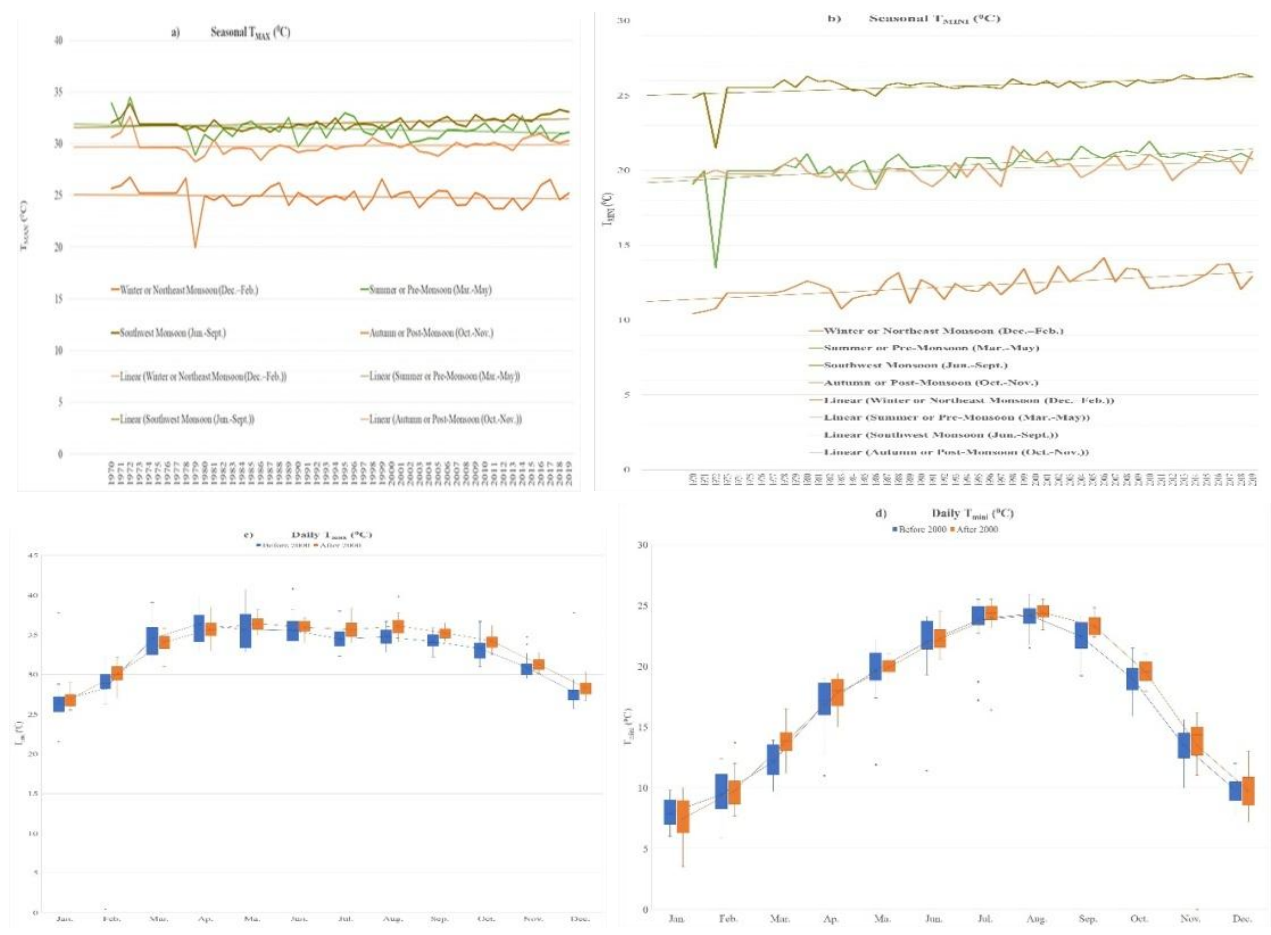

Figure 1. The figure shows a variation in (a) seasonal average $\mathrm{T}_{\max }$., (b) seasonal average $\mathrm{T}_{\text {mini. }}$, (c) daily mean $\mathrm{T}_{\max }$. and (d) daily mean $\mathrm{T}_{\text {ermini. }}$ before the 2000 s'and after the 2000s' century 


\section{Changes in relative humidity}

The daily average relative humidity was found to gradually decrease after the 2000s' century in Rangpur division (Figure 5a). Meteorological daily relative humidity (\%) data shows that in winter (Dec-Jan) 0.351 (\%) differences, monsoon (Jun-Sep) 1.706 (\%) differences and post-monsoon (Oct-Nov) $2.14(\%)$ differences between before 2000s' century and after 2000s' century, whereas in pre-monsoon (Mar-May) 1.632 $(\%)$ increase from (BMD) in Rangpur division.

\section{Changes in sunshine hours}

The decreasing rate of daily average sunshine (hours) was recorded after the '2000s' century in Rangpur division. Meteorological daily sunshine hours (Fig. 2) data shows that in winter (Dec-Jan) 1.789 hours differences, pre-monsoon (Mar-May) 0.906 hours differences and post-monsoon (Oct-Nov) 0.831 hours differences between before 2000s' century and after 2000s' century, whereas in monsoon (Jun-Sep) 0.307 hours differences i.e., similar or near about half hours decreasing rate from (BMD) in Rangpur division.

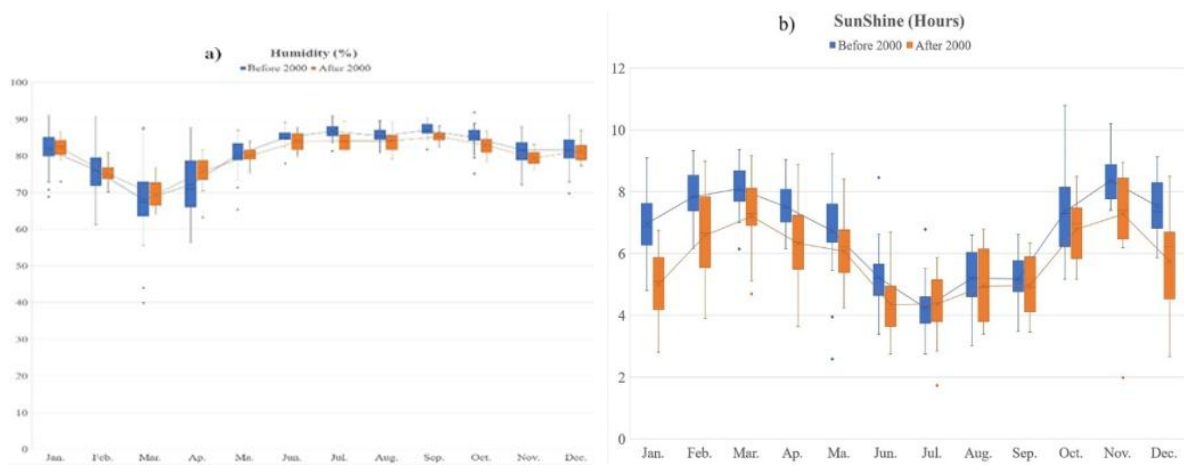

Figure 2. The figure shows a variation in (a) relative humidity (\%) and (b) sunshine (hours) from 1970 to 2019 in Rangpur division

\section{Changes in rainfall pattern}

Table 2 shows the recorded change in precipitation for the last 50 years. The mean annual precipitation in Rangpur division from 1970 to 2019 is $175.60 \mathrm{~mm}$ from (BMD), the monsoon precipitation has seen an increase over time, especially from the ' $80 \mathrm{~s}$ to the $90 \mathrm{~s}$ '. The data also show that there has been an increase in the total annual precipitation in the '2000s' century and that was due to increased precipitation in the Pre-monsoon, monsoon, and Post monsoon, while the pre-and post-monsoon periods have been dryer than in the '2010s to 2019s' (Bhatta, 2015). 
Table 2. Changes in average rainfall patterns (in mm) from 1970 to 2019 in Rangpur division

\begin{tabular}{cccccc}
\hline $\begin{array}{c}\text { Range (in } \\
\text { years) }\end{array}$ & $\begin{array}{c}\text { Average } \\
\text { annual }\end{array}$ & $\begin{array}{c}\text { Winter } \\
\text { (Dec-Feb) }\end{array}$ & $\begin{array}{c}\text { Pre-monsoon } \\
\text { (Mar-May) }\end{array}$ & $\begin{array}{c}\text { Monsoon } \\
\text { (Jun-Sep) }\end{array}$ & $\begin{array}{c}\text { Post -monsoon } \\
\text { (Oct-Nov) }\end{array}$ \\
\hline $1970-79$ & 160.819 & 6.57 & 105.67 & 360.5 & 68.75 \\
$1980-89$ & 193.434 & 11.33 & 145.5 & 476.1 & 63.2 \\
$1990-99$ & 185.833 & 11.23 & 119.83 & 413.05 & 92.3 \\
$2000-2009$ & 192.85 & 7.6 & 156.53 & 388.175 & 134.55 \\
$2010-2019$ & 145.0746 & 4.96 & 132.03 & 312.83 & 39.29032 \\
\hline
\end{tabular}

\section{Changes in wind speed}

The daily average wind speed was found to gradually increase after the 2000s' century in the Rangpur division (Fig. 3). Meteorological daily wind speed data shows that in winter (Dec-Jan) $0.91204 \mathrm{~m} / \mathrm{s}$ and post-monsoon (Oct-Nov) $0.796341 \mathrm{~m} / \mathrm{s}$ differences increase between before 2000s' century and after 2000s' century from (BMD) in Rangpur division.

\section{Changes in solar radiation intensity}

The daily average solar radiation intensity was found to gradually decrease after the 2000s' century in Rangpur division (Figure 6b). Meteorological daily solar radiation data shows that in winter (Dec-Jan) (16.35 21.43 17.24) $\mathrm{w} / \mathrm{m}^{2}$ differences, monsoon (Jun-Sep) (11.86 14.70 11.57) w/m² differences, post-monsoon (Oct-Nov) (2.35 8.22 $6.02) \mathrm{w} / \mathrm{m}^{2}$ differences and pre-monsoon (Mar-May) (10.054 $\left.7.86 \quad 10.31\right) \mathrm{w} / \mathrm{m}^{2}$ between before 2000s' century and after 2000s' century from (BMD) in Rangpur division.

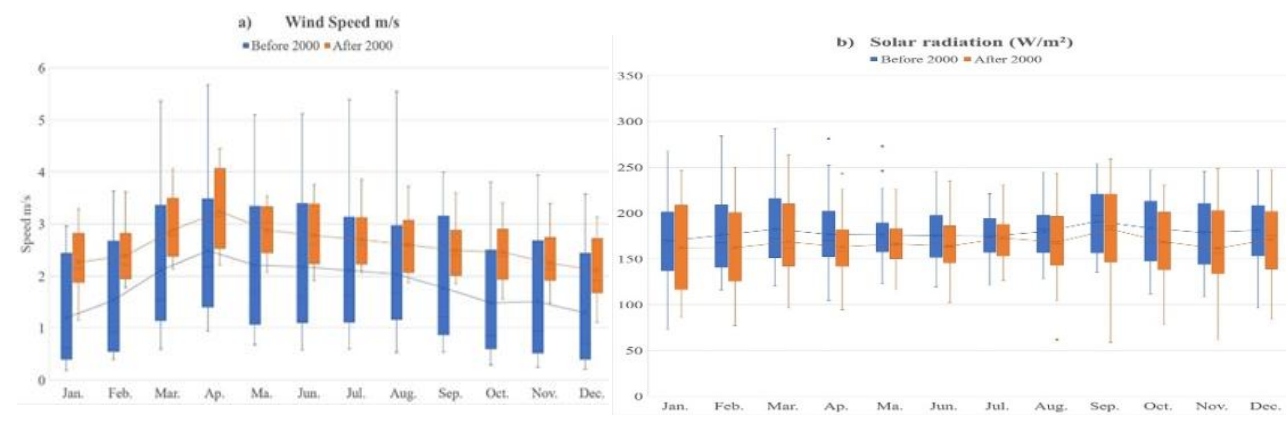

Figure 3. The figure shows a variation in (a) wind speed $(\mathrm{m} / \mathrm{s})$ and (b) solar radiation $\left(\mathrm{w} / \mathrm{m}^{2}\right)$ from 1979-2017 in Rangpur division

\section{Char dwellers major income sources}

Most of the char dwellers in the study area were involved in agriculture (main occupation). The study revealed that $60 \%, 60 \%$ and $62 \%$ char dwellers were engaged 
in agriculture, $21 \%, 18 \%$ and $19 \%$ in livestock rearing, $10 \%, 15 \%$ and $11 \%$ in fishing, $5 \%, 5 \%$ and $5 \%$ in daily labor, $3 \%, 1 \%$ and $2 \%$ in small business and average $1 \%$ others in South Shivkuthir, Char Bazra and Char
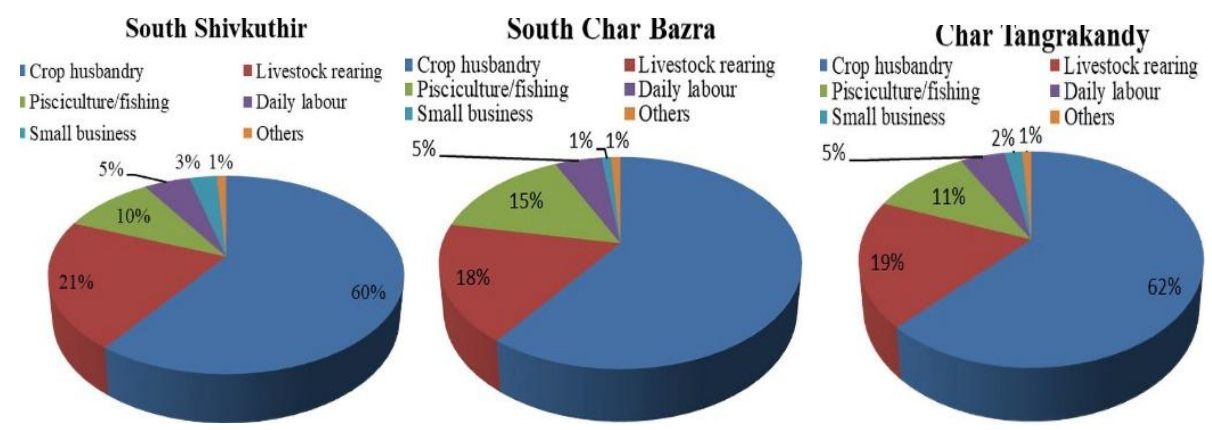

Figure 4. Char dwellers major income sources

Tangrakandy respectively (Fig.4). Roy et al. (2019) stated that 66\% agriculture farming, $7 \%$ agriculture wage labor, $4 \%$ salaried, $8 \%$ business and $15 \%$ others which agreed more or less similar of the study. The evaluation of climate change impacts on agricultural production, food supply and agriculture-based livelihoods must consider the characteristics of the agro-ecosystem where particular climate-induced changes in biochemical processes are occurring, in order to determine the extent to which such changes in livelihood status as perceived by respondents among the various problems caused by climate change within 3 sites are below:

Table 3. Respondents perceiving on livelihood status among the various problems caused by climate change

\begin{tabular}{lcccccc}
\hline A. Income & $\begin{array}{c}\text { South Shivkuthir } \\
(\mathrm{N}=100)\end{array}$ & \multicolumn{2}{c}{$\begin{array}{c}\text { Char Bazra } \\
(\mathrm{N}=150)\end{array}$} & $\begin{array}{c}\text { Char Tangrakandy } \\
(\mathrm{N}=150)\end{array}$ \\
\cline { 2 - 7 } & $\begin{array}{c}\text { Curren } \\
\text { tly }\end{array}$ & $\begin{array}{c}15 \text { years } \\
\text { ago }\end{array}$ & $\begin{array}{c}\text { Curr } \\
\text { ently }\end{array}$ & $\begin{array}{c}15 \text { years } \\
\text { ago }\end{array}$ & $\begin{array}{c}\text { Current } \\
\text { ly }\end{array}$ & $\begin{array}{c}15 \text { years } \\
\text { ago }\end{array}$ \\
\hline \multicolumn{7}{c}{ a. Agricultural sources } \\
1. Paddy & $84 \%$ & $10 \%$ & $81 \%$ & $19 \%$ & $83 \%$ & $16 \%$ \\
2. Pulses and oil seeds & $85 \%$ & $24 \%$ & $85 \%$ & $26 \%$ & $86 \%$ & $21 \%$ \\
3. Fruit & $81 \%$ & $21 \%$ & $83 \%$ & $18 \%$ & $82 \%$ & $17 \%$ \\
4. Vegetables & $85 \%$ & $22 \%$ & $85 \%$ & $25 \%$ & $83 \%$ & $23 \%$ \\
5. kaljira, ginger and & $75 \%$ & $19 \%$ & $70 \%$ & $21 \%$ & $73 \%$ & $18 \%$ \\
turmeric (Spices) & & & & & & \\
6. Fisheries/Aquaculture & $50 \%$ & $61 \%$ & $55 \%$ & $62 \%$ & $51 \%$ & $60 \%$ \\
7. Crab & $51 \%$ & $61 \%$ & $66 \%$ & $61 \%$ & $60 \%$ & $67 \%$ \\
\hline
\end{tabular}




\begin{tabular}{|c|c|c|c|c|c|c|}
\hline \multirow[t]{2}{*}{ A. Income } & \multicolumn{2}{|c|}{$\begin{array}{l}\text { South Shivkuthir } \\
\qquad(\mathrm{N}=100)\end{array}$} & \multicolumn{2}{|c|}{$\begin{array}{l}\text { Char Bazra } \\
(\mathrm{N}=150)\end{array}$} & \multicolumn{2}{|c|}{$\begin{array}{c}\text { Char Tangrakandy } \\
(\mathrm{N}=150)\end{array}$} \\
\hline & $\begin{array}{c}\text { Curren } \\
\text { tly }\end{array}$ & $\begin{array}{l}15 \text { years } \\
\text { ago }\end{array}$ & $\begin{array}{l}\text { Curr } \\
\text { ently }\end{array}$ & $\begin{array}{l}15 \text { years } \\
\text { ago }\end{array}$ & $\begin{array}{c}\text { Current } \\
\text { ly }\end{array}$ & $\begin{array}{c}15 \text { years } \\
\text { ago }\end{array}$ \\
\hline 8. Livestock & $65 \%$ & $25 \%$ & $64 \%$ & $25 \%$ & $63 \%$ & $27 \%$ \\
\hline 9. Poultry & $67 \%$ & $43 \%$ & $65 \%$ & $45 \%$ & $67 \%$ & $48 \%$ \\
\hline $\begin{array}{l}\text { 10. Wood lot/bamboo } \\
\text { garden }\end{array}$ & $65 \%$ & $20 \%$ & $63 \%$ & $19 \%$ & $61 \%$ & $21 \%$ \\
\hline 11. Nursery & $80 \%$ & $25 \%$ & $78 \%$ & $23 \%$ & $73 \%$ & $26 \%$ \\
\hline $\begin{array}{l}\text { 12. Other (Tobaco, } \\
\text { potato, etc.) }\end{array}$ & $73 \%$ & $33 \%$ & $74 \%$ & $39 \%$ & $78 \%$ & $35 \%$ \\
\hline \multicolumn{7}{|c|}{ b. Non-agricultural sources } \\
\hline 1. Small business & $39 \%$ & $35 \%$ & $41 \%$ & $31 \%$ & $40 \%$ & $33 \%$ \\
\hline 2. The laborer & $34 \%$ & $26 \%$ & $35 \%$ & $31 \%$ & $30 \%$ & $31 \%$ \\
\hline $\begin{array}{l}\text { 3.Rickshaw/Van/Nasimon } \\
\text { /Horse/Carriage/Motorcy } \\
\text { cle Driving }\end{array}$ & $36 \%$ & $13 \%$ & $40 \%$ & $19 \%$ & $38 \%$ & $9 \%$ \\
\hline 4. Char sand sold & $31 \%$ & $19 \%$ & $36 \%$ & $14 \%$ & $36 \%$ & $17 \%$ \\
\hline 5. Making handicrafts & $38 \%$ & $15 \%$ & $29 \%$ & $14 \%$ & $21 \%$ & $21 \%$ \\
\hline $\begin{array}{l}\text { 6. Remittance } \\
\text { (domestic/foreign) }\end{array}$ & $40 \%$ & $20 \%$ & $32 \%$ & $15 \%$ & $34 \%$ & $23 \%$ \\
\hline $\begin{array}{l}\text { 7. Services } \\
\text { (Govt./NGO/Private) }\end{array}$ & $20 \%$ & $13 \%$ & $23 \%$ & $21 \%$ & $19 \%$ & $21 \%$ \\
\hline \multirow{3}{*}{$\begin{array}{l}\text { B. Food security } \\
\text { (availability of nutritious } \\
\text { food every month of the } \\
\text { year) }\end{array}$} & \multicolumn{6}{|c|}{ The amount of food at different times } \\
\hline & \multicolumn{2}{|c|}{$\begin{array}{l}\text { South Shivkuthir } \\
(\mathrm{N}=100)\end{array}$} & \multicolumn{2}{|c|}{$\begin{array}{c}\text { Char Bazra } \\
(\mathrm{N}=150)\end{array}$} & \multicolumn{2}{|c|}{$\begin{array}{c}\text { Char Tangrakandy } \\
(\mathrm{N}=150)\end{array}$} \\
\hline & $\begin{array}{c}\text { Curre } \\
\text { ntly }\end{array}$ & $\begin{array}{c}15 \text { years } \\
\text { ago }\end{array}$ & $\begin{array}{c}\text { Curre } \\
\text { ntly }\end{array}$ & $\begin{array}{l}15 \text { years } \\
\text { ago }\end{array}$ & $\begin{array}{c}\text { Current } \\
\text { ly }\end{array}$ & $\begin{array}{c}15 \text { years } \\
\text { ago }\end{array}$ \\
\hline 1. Boishakh (April-May) & $57 \%$ & $16 \%$ & $60 \%$ & $16 \%$ & $67 \%$ & $16 \%$ \\
\hline 2. Jaistha (May-June) & $73 \%$ & $17 \%$ & $75 \%$ & $19 \%$ & $73 \%$ & $17 \%$ \\
\hline 3. Ashar (June-July) & $85 \%$ & $21 \%$ & $83 \%$ & $21 \%$ & $85 \%$ & $19 \%$ \\
\hline 4. Shravan (July-August) & $83 \%$ & $22 \%$ & $84 \%$ & $23 \%$ & $85 \%$ & $25 \%$ \\
\hline $\begin{array}{l}\text { 5. Bhadra (August- } \\
\text { September) }\end{array}$ & $85 \%$ & $11 \%$ & $83 \%$ & $18 \%$ & $75 \%$ & $11 \%$ \\
\hline $\begin{array}{l}\text { 6. Ashwin (September- } \\
\text { October) }\end{array}$ & $89 \%$ & $25 \%$ & $87 \%$ & $27 \%$ & $79 \%$ & $23 \%$ \\
\hline
\end{tabular}




\begin{tabular}{|c|c|c|c|c|c|c|}
\hline \multirow{3}{*}{$\begin{array}{l}\text { B. Food security } \\
\text { (availability of nutritious } \\
\text { food every month of the } \\
\text { year) }\end{array}$} & \multicolumn{6}{|c|}{ The amount of food at different times } \\
\hline & \multicolumn{2}{|c|}{$\begin{array}{l}\text { South Shivkuthir } \\
(\mathrm{N}=100)\end{array}$} & \multicolumn{2}{|c|}{$\begin{array}{l}\text { Char Bazra } \\
(\mathrm{N}=150)\end{array}$} & \multicolumn{2}{|c|}{$\begin{array}{c}\text { Char Tangrakandy } \\
(\mathrm{N}=150)\end{array}$} \\
\hline & $\begin{array}{c}\text { Curre } \\
\text { ntly }\end{array}$ & $\begin{array}{l}15 \text { years } \\
\text { ago }\end{array}$ & $\begin{array}{c}\text { Curre } \\
\text { ntly }\end{array}$ & $\begin{array}{l}15 \text { years } \\
\text { ago }\end{array}$ & $\begin{array}{c}\text { Current } \\
\text { ly }\end{array}$ & $\begin{array}{c}15 \text { years } \\
\text { ago }\end{array}$ \\
\hline $\begin{array}{l}\text { 7. Kartik (October- } \\
\text { November) }\end{array}$ & $81 \%$ & $33 \%$ & $86 \%$ & $35 \%$ & $61 \%$ & $33 \%$ \\
\hline $\begin{array}{l}\text { 8. Agrahayan (November- } \\
\text { December) }\end{array}$ & $85 \%$ & $24 \%$ & $85 \%$ & $27 \%$ & $75 \%$ & $24 \%$ \\
\hline $\begin{array}{l}\text { 9. Poush (December- } \\
\text { January) }\end{array}$ & $85 \%$ & $20 \%$ & $83 \%$ & $19 \%$ & $83 \%$ & $49 \%$ \\
\hline $\begin{array}{l}\text { 10. Magh (January- } \\
\text { February) }\end{array}$ & $80 \%$ & $13 \%$ & $74 \%$ & $15 \%$ & $84 \%$ & $13 \%$ \\
\hline $\begin{array}{l}\text { 11. Falgun (February- } \\
\text { March) }\end{array}$ & $77 \%$ & $24 \%$ & $77 \%$ & $24 \%$ & $77 \%$ & $24 \%$ \\
\hline 12. Chaitra (March-April) & $81 \%$ & $30 \%$ & $82 \%$ & $35 \%$ & $82 \%$ & $36 \%$ \\
\hline \multirow[t]{2}{*}{ C. Welfare } & \multicolumn{6}{|c|}{ Satisfaction levels at different times } \\
\hline & $\begin{array}{l}\text { Curre } \\
\text { ntly }\end{array}$ & $\begin{array}{l}15 \text { years } \\
\text { ago }\end{array}$ & $\begin{array}{l}\text { Curre } \\
\text { ntly }\end{array}$ & $\begin{array}{l}15 \text { years } \\
\text { ago }\end{array}$ & $\begin{array}{c}\text { Current } \\
\text { ly }\end{array}$ & $\begin{array}{c}15 \text { years } \\
\text { ago }\end{array}$ \\
\hline $\begin{array}{l}\text { 1. Access to nutritious } \\
\text { food }\end{array}$ & $82 \%$ & $25 \%$ & $89 \%$ & $22 \%$ & $79 \%$ & $22 \%$ \\
\hline $\begin{array}{l}\text { 2. Access to safe drinking } \\
\text { water }\end{array}$ & $88 \%$ & $27 \%$ & $88 \%$ & $27 \%$ & $88 \%$ & $27 \%$ \\
\hline $\begin{array}{l}\text { 3. Ability to support child } \\
\text { education costs }\end{array}$ & $21 \%$ & $19 \%$ & $31 \%$ & $20 \%$ & $31 \%$ & $25 \%$ \\
\hline $\begin{array}{l}\text { 4. Easy availability of } \\
\text { irrigation water }\end{array}$ & $47 \%$ & $31 \%$ & $47 \%$ & $31 \%$ & $37 \%$ & $31 \%$ \\
\hline 5. Sanitary latrine access & $43 \%$ & $26 \%$ & $42 \%$ & $26 \%$ & $45 \%$ & $26 \%$ \\
\hline $\begin{array}{l}\text { 6. Availability of fire } \\
\text { wood }\end{array}$ & $75 \%$ & $25 \%$ & $75 \%$ & $25 \%$ & $75 \%$ & $25 \%$ \\
\hline $\begin{array}{l}\text { 7. Financial ability to } \\
\text { provide better drug } \\
\text { support for family } \\
\text { members }\end{array}$ & $25 \%$ & $14 \%$ & $25 \%$ & $14 \%$ & $25 \%$ & $14 \%$ \\
\hline $\begin{array}{l}\text { 8. There are quality } \\
\text { houses to stay }\end{array}$ & $60 \%$ & $25 \%$ & $62 \%$ & $28 \%$ & $65 \%$ & $28 \%$ \\
\hline $\begin{array}{l}\text { 9. Daily expenses for } \\
\text { family members }\end{array}$ & $58 \%$ & $25 \%$ & $60 \%$ & $22 \%$ & $62 \%$ & $29 \%$ \\
\hline
\end{tabular}




\section{Income}

Agricultural sources like paddy, pulses and oil seeds, fruit, vegetables, kaljira, ginger and turmeric (Spices), etc. earn fairly good (70 to 85\%) than last 15 years ago (10 to $26 \%$ ) good whereas fisheries/aquaculture and crab 50 to $51 \%$ earn good than last 15 years ago (60 to 66\%) fairly good. Livestock is the best income source of char dwellers (63 to $65 \%$ ) very good, poultry (65 to 67\%) fairly good than last 15 years ago (25 to $27 \%$ ) fairly good to good (43 to 48\%), wood lot, nursery and others income sources earn fairly good to good (61 to 80\%) than last 15 years ago (19 to $39 \%$ ) bad to very bad (Table 3). b) Non-agricultural sources like small business, the laborer, rickshaw/van/nasimon/horse/motorcycle driving, char sand sold, making handicrafts, remittance (domestic/foreign), and services (Govt./NGO/private) etc. earn fairly good to good (19 to 41\%) than last 15 years ago (9 to 35\%) good to very bad in South Shivkuthir, Char Bazra and Char Tangrakandy, respectively.

\section{Food security}

In Boishakh (Apr-Ma), Jaistha (Ma-Jun) to Ashar (Jun-Jul) i.e. pre-monsoon to early monsoon season (Table 2) in char area, April to July are the hottest months (Figure 4a), highest maximum temperature ranging from $32-36^{\circ} \mathrm{C}$ is attained in the northern districts. Thunder storms occur in the season known as 'Kalbaishakhi, heavy rainfall with hails, flash flood occurs. Resulting char dwellers became workless, can't cultivated land and food deficiency occurred (85 to 57\%) necessary availability more than last 15 years ago (16 to 21\%) less availability. In Shravan (Juy-Aug), Bhadra (Aug-Sept) to Ashwin (Sept-Oct) i.e., monsoon to post-monsoon, wind speed remains light to moderate, the summer extreme temperatures fall, caused heavy rainfall and cyclone. Resulting char dwellers became unemployed, inundated crop land and house, house and land erosion, drinking water and food deficiency etc. occur (75 to $89 \%$ ) necessary availability more than last 15 years ago (11 to $25 \%$ ) less availability to very little. In Kartik (Oct-Nov), Agrahayan (Nov-Dec) to Poush (DecJan) i.e. winter season. Rainfall decreases considerably, temperature falls noticeably, sometimes lowest temperature minimum fall below $10^{\circ} \mathrm{C}$. At the time Monga (OctNov) or starvation started in char areas, became food deficiency occur (61 to 85\%) less availability more than last 15 years ago (19 to 49\%) very little. In Magh (JanFeb), Falgun (Feb-Mar) to Chaitra (Mar-Apr) i.e., winter to early pre-monsoon season, very light northerly winds, dry weather and clear to occasionally cloudy sky with fog is the common characteristics of this season. The mean temperature is in the range of $8-25^{\circ} \mathrm{C}$, sometimes minimum temperature goes below than $10^{\circ} \mathrm{C}$ and cold wave situation occurs in northern part of the country, less relative humidity (Figure $5 a$ ) but high sunshine (hours) (Figure 5b) which is perfect for winter/robi crops (74 to $84 \%$ ) less availability more than last 15 years ago (13 to $36 \%$ ) very little.

\section{Welfare}

Respondent answered in relation of access to nutritious food, safe drinking water and daily expenses (58 to $88 \%$ ) satisfactory more than last 15 years ago (22 to $2 \%$ ) 
disappointing to extremely frustrating. Easy availability of irrigation water, sanitary latrine access, availability of fire wood and quality houses to stay (43 to 75\%) satisfactory to disappointing more than last 15 years ago (25 to $31 \%$ ) disappointing to extremely frustrating. Ability to support child education costs and provide better drug support for family members (21 to $31 \%$ ) satisfactory more than last 15 years ago (14 to $15 \%)$ extremely frustrating.

Table 4. Climatic stressors and their impacts on char livelihoods

\begin{tabular}{ll}
\hline $\begin{array}{l}\text { Climatic } \\
\text { stressors }\end{array}$ & \multicolumn{1}{c}{ Impacts on char livelihoods } \\
\hline $\begin{array}{l}\text { Flooding } \\
\text { and } \\
\text { inundation }\end{array}$ & $\begin{array}{l}\text { Damage of rice, wheat, crops, and vegetables; the Death of livestock and } \\
\text { poultry; } \\
\text { Devastating homestead lands; Infrastructures, markets, and communication } \\
\text { networks; Decrease in labor force activities; destroying income source, } \\
\text { different disease attack. }\end{array}$ \\
$\begin{array}{l}\text { Riverbank } \\
\text { erosion }\end{array}$ & $\begin{array}{l}\text { Engulfing cultivable and homestead lands; Destroying crops' fields; } \\
\text { Disappearing homes, shops, vegetable gardens, village roads, and markets }\end{array}$ \\
$\begin{array}{l}\text { Drought and } \\
\text { extreme } \\
\text { temperature }, \\
\text { heatwave }\end{array}$ & $\begin{array}{l}\text { Affecting paddy, vegetables, crop cycles and diversification; Crisis of } \\
\text { reduction in drinking water sources, migration and loss of livestock; Crisis } \\
\text { of agro-based activities, dying meadows, faltering yields. }\end{array}$ \\
$\begin{array}{l}\text { Huge and } \\
\text { untimely } \\
\text { rainfalls }\end{array}$ & $\begin{array}{l}\text { Decreasing rice production, winter crops, and vegetable growth and } \\
\text { seedlings; }\end{array}$ \\
$\begin{array}{l}\text { Crisis in rainwater harvesting, crop cycle change; Increased pests and } \\
\text { pathogens in crops, livestock disease, and drought (particularly affecting } \\
\text { paddy crops and vegetables), price hikes }\end{array}$ \\
$\begin{array}{l}\text { Attacking pests and insects, crops and livestock diseases; Limiting labor } \\
\text { force activities and loss of vegetables and crops production. }\end{array}$ \\
\hline
\end{tabular}

\section{Effect on agricultural practice system and livelihood}

In the study area, it was a noticeable change in crop practices compared to the previous. The farmers growing major cultivated crops were rice, jute, potato, nut, maize, cabbage, Chili, pumpkin, cauliflower, bean, eggplant, cucumber, tomato, carrot, radish, tobacco, and the varieties of rice are Binadhan-7, Aush, Skim (ACI-2, BR-3, and BR-8) and Aman (Sarna, Guti-Sarna, Sarna-29, Sarna-52, BR-11, and China), etc. rather than cultivating the traditional crops. This change in crop practice is due to the increases of daily average $\mathrm{T}_{\max }$ and $\mathrm{T}_{\min }$, rainfall pattern, sunshine hours, i.e., climatic change. Temperature and its intensity have been increased day by day. 
Sunshine hours shorting (before 2000s' than after 2000s' century), erratic rainfall with long-lasting alterations is directly made a linkage with another climatic variable which may appear unbearable and unexpected events. Particularly, households headed by educated heads, having more family size in productive age group, having fewer dependents, access of information, having financial and extension services, having easy access of physical capitals, having better infrastructure and built up assets were found to be the contributing factors which make difference in adaptive capacity (Asfaw et al., 2021). The majority of respondents in the study area are engaged in mixed farming livelihood systems (livestock and crop production). Adaptation measures in the livestock production system has also been made using herd splitting, herd diversification, livestock mobility, use of sheep and goats rather than cattle, engaging in crop production, temporal migration and off-farm activities. According to the questionnaire, char dwellers were asked about climatic stressors and their impacts (Table 4) on their livelihoods, by remember, understanding, applied, analyzed, evolution, and innovation were listed below:

\section{CONCLUSION}

Most of the char dwellers are either poor or hardcore poor due to flooding, riverbank erosion, extreme temperature, uneven rainfall, low humidity, decreasing sunshine hours, and cold waves are influencing their agricultural practices and major source of income. Short-term adjustments to climate change include efforts to optimize production without major system changes like change in crop variety and planting date, use of irrigation and water harvesting schemes, tree planting etc., in long-term, land use change, crops with high inter-annual variability in production may be substituted by crops with lower productivity but more stable yields and also useful for the conservation of soil moisture. Besides, slow technology transfer, quality seeds supply, adequate irrigation, storage, marketing and credit facilities. It is an important note that sometimes fertilizer and pesticide require very less or no need because of sediment. So, for sustainable livelihoods, immediate development programs should be taken to enhance adaptive capacity.

\section{ACKNOWLEDGEMENT}

The authors are grateful to the Ministry of Science and Technology (MoST), Government of the People's Republic of Bangladesh for providing financial support to implement the research work purposively.

\section{REFERENCES}

Asfaw, A., Bantider, A., Simane, B. and Hassen, A. (2021). Smallholder farmers' livelihood vulnerability to climate change-induced hazards: agroecology-based comparative analysis in Northcentral Ethiopia (Woleka Sub-basin). Heliyon, 7(4): e06761. 
Bhatta, L.D., van Oort, B.E.H., Stork, N.E. and Baral, H. (2015). Ecosystem services and livelihoods in a changing climate: Understanding local adaptations in the Upper Koshi, Nepal. International Journal of Biodiversity Science, Ecosystem Services \& Management, 11(2): 145-155.

Ellis, F. (2000). Rural livelihoods and diversity in developing countries. Oxford university Press.

Government of Bangladesh, Ministry of Environment and Forest. (2005). National Adaptation Programs of Action (NAPA), Dhaka, Bangladesh.

Government of Bangladesh. (2011). The Sixth Five-year Plan, 2011-2015. Ministry of Planning, Govt. of the People's Republic of Bangladesh, Dhaka

Hossain, B., Sohel, M.S. and Ryakitimbo, C.M. (2020). Climate change induced extreme flood disaster in Bangladesh: Implications on people's livelihoods in the Char Village and their coping mechanisms. Progress in Disaster Science, 6: 100079.

Islam, M.R. (2018). Climate change, natural disasters and socioeconomic livelihood vulnerabilities: migration decision among the Char land people in Bangladesh. Social Indicators Research, 136(2): 575-593.

Islam, M.R., and Hossain, D. (2014). Island char resources mobilization (ICRM): Changes of livelihoods of vulnerable people in Bangladesh. Social Indicators Research, 117(3): 1033-1054.

Kelly, C. and Chowdhury, M.K. (2002). Poverty, disasters and the environment in Bangladesh: a quantitative and qualitative assessment of causal linkages. Bangladesh Issues Paper. UK Department for International Development, Dhaka.

Meehl, G.A., Washington, W.M., Wigley, T.M.L., Arblaster, J.M. and Dai, A. (2003). Solar and greenhouse gas forcing and climate response in the twentieth century. Journal of Climate, 16(3): 426-444.

Mondal, M.S., Rahman, M.A., Mukherjee, N., Huq, H., and Rahman, R. (2015). Hydroclimatic hazards for crops and cropping system in the chars of the Jamuna River and potential adaptation options. Natural hazards, 76(3): 1431-1455.

Paul, S., and Islam, M.R. (2015). Ultra-poor char people's rights to development and accessibility to public services: A case of Bangladesh. Habitat International, 48: 113121.

Reed, M.S., Podesta, G., Fazey, I., Geeson, N., Hessel, R., Hubacek, K. and Thomas, A.D. (2013). Combining analytical frameworks to assess livelihood vulnerability to climate change and analyze adaptation options. Ecological Economics, 94: 66-77.

Rind, D. and Overpeck, J. (1993). Hypothesized causes of decade-to-century-scale climate variability: climate model results. Quaternary Science Reviews, 12(6): 357-374.

Roy, D., Sarker Dev, D. and Sheheli, S. (2019). Food security in Bangladesh: insight from available literature. Journal of Nutrition and Food Security, 4(1): 66-75.

Van den Besselaar, E.J., Sanchez-Lorenzo, A., Wild, M., Klein Tank, A.M. and De Laat, A.T.J. (2015). Relationship between sunshine duration and temperature trends across Europe since the second half of the twentieth century. Journal of Geophysical Research: Atmospheres, 120(20): 10-823. 
Villalba, R., Cook, E.R., D’arrigo, R.D., Jacoby, G.C., Jones, P.D., Salinger, M.J. and Palmer, J. (1997). Sea-level pressure variability around Antarctica since AD 1750 inferred from subantarctic tree-ring records. Climate Dynamics, 13(6): 375-390.

Wood, S.A., Jina, A.S., Jain, M., Kristjanson, P. and DeFries, R.S. (2014). Smallholder farmer cropping decisions related to climate variability across multiple regions. Global Environmental Change, 25: 163-172.

Zhang, T., Huang, Y. and Yang, X. (2013). Climate warming over the past three decades has shortened rice growth duration in China and cultivar shifts have further accelerated the process for late rice. Global Change Biology, 19(2): 563-570. 